\title{
Thoughts and Strategies of Sponge City Construction Planning: A Case Study of Pingxiang, Jiangxi Province
}

\author{
Zhenzhen Wang, Yujie Lou, Benxiao Zhang, Bingcheng Shi \\ School of Literature and Law, Zhejiang Agricultural and Forestry University, Hangzhou, China \\ Email: wzz19950821wyyx@163.com
}

How to cite this paper: Wang, Z.Z., Lou, Y.J., Zhang, B.X. and Shi, B.C. (2020) Thoughts and Strategies of Sponge City Construction Planning: A Case Study of Pingxiang, Jiangxi Province. Open Journal of Civil Engineering, 10, 43-54. https://doi.org/10.4236/ojce.2020.101005

Received: December 31, 2019

Accepted: March 17, 2020

Published: March 20, 2020

Copyright $\odot 2020$ by author(s) and Scientific Research Publishing Inc. This work is licensed under the Creative Commons Attribution International License (CC BY 4.0).

http://creativecommons.org/licenses/by/4.0/

\begin{abstract}
At present and for a long time in the future, urbanization in China will maintain a rapid development speed. After the rainstorm, the phenomenon of "sea views" is common. The direct reason is that the urban drainage system and the ground drainage system cannot afford the large flow of water in a short period of time, but the most fundamental reason is that the artificial construction environment changes the water storage and drainage function of the ground under the natural state. "Sponge city construction" came into being. This paper mainly analyzes and studies the sponge city construction in Pingxiang City, Jiangxi Province, and uses the method of field investigation and literature data to clarify the ideas of the sponge city construction in Pingxiang City and summarize the successful experience, which can provide a reference for the subsequent "sponge city development" ideas.
\end{abstract}

\section{Keywords}

Sponge City Construction Planning Pingxiang

\section{Introduction}

In recent years, cities in developed countries have achieved success in new urban construction, such as the best management measures and low-impact development technology in the United States, the sound water cycle system in Japan, the water-sensitive urban design in Australia, and the sustainable urban drainage system in the United Kingdom, which can be used for reference and application in the construction of sponge cities in China to form a unique form of urban construction [1].

At present, the sponge cities under construction in China are Pingxiang City 
in Jiangxi Province, Zhenjiang City in Jiangsu Province, Jiaxing City in Zhejiang Province, Xiamen in Fujian Province, Chizhou in Anhui Province, Jinan in Shandong Province and Changde in Hunan Province in the eastern and southern regions; Wuhan in Hubei Province, Hebi in Henan Province and Qian'an in Hebei Province in the central region; Nanning in Guangxi Province, Suining in Sichuan Province, Gui'an New Area in Guizhou Province and Chongqing in the southwestern region; Baicheng in Jilin Province in the northeastern region; the follow-up cities such as Xixian New Area in the central and western regions of Shaanxi Province [2]. Regionally, these cities are mainly concentrated in the southern and eastern regions with more precipitation, while other cities are scattered in a few areas in the north. In April 2015, Pingxiang City broke through the tight encirclement, and through the joint efforts of the people and government staff of the whole city, it was successfully selected as one of the pilot cities of the first batch of sponge cities. However, in the first batch of approved pilot cities, Pingxiang's resources and conditions lag behind other similar cities, so sponge city in Pingxiang's construction and implementation process inevitably consumes more financial and material resources than other cities, in order to meet the corresponding construction requirements and achieve good results.

This paper will focus on how to build a sponge city with weak advantages in Pingxiang City. Previous studies on sponge city are mainly focused on the areas with developed economy and outstanding congenital advantages, so the research object is more special and has better research value.

\section{Sponge City Overview}

\subsection{Sponge City Concept}

Sponge city refers to the new construction and development mode of cities to cope with urban water accumulation, waterlogging and other problems, which has a special regulation function on precipitation. It can dissolve the tense relationship between urban ecological environment and water resources fundamentally. This low-impact development mode can effectively reduce the non-point source pollution of rainwater, improve the utilization efficiency of rainwater, improve the water shortage problem of cities, make the ecological balance reach a higher level, change the traditional state of rainwater drainage and impoundment, make the city develop better, make full use of resources, and build a new city with beautiful environment and harmonious coexistence between man and nature [3].

\subsection{Key Points of Sponge City Construction}

\subsubsection{Planning Ideas}

Under the background of sponge city construction in China, "planning" adopts special construction ideas, involving ecology, landscape, municipal and urban planning and other fields, to build a new sponge pattern and a green sponge system, which is a good promotion education for the improvement of urban struc- 
ture and the formation of a new urban pattern.

Combined with the relevant technical indicators of the sponge city, the waterlogging-prone areas in the urban focus on transformation. To finalize the details of the plan to maintain a close dialogue and conversation with the design unit to ensure that the feasibility and scientific scheme. Where necessary, laying permeable bricks, as far as possible with permeable asphalt, permeable concrete hardened pavement, the premise is to maintain the design strength, use safety. The renewal and reconstruction of the drainage pipeline should be consistent with the use and construction requirements of the sponge city as far as possible, and the water surface of the river and lake should be constructed together with the newly built sponge facilities to form a complementary and coordinated organic system. The specific design scheme should be examined by the planning department and the municipal sponge office, and be replied within five working days. In the construction process, not only the overall function should be paid attention to, but also the specific details should not be ignored. The purpose of controlling the process and details is to reduce the mistakes in the work. The transformed city should fully reflect the strong advantages of sponge body and become a characteristic livelihood project satisfying the people.

\subsubsection{Application of the Government's PPP Model in Sponge City}

PPP model simply refers to a public-private partnership, risk sharing, benefit sharing, providing public goods and services production and operation model. Is the use of social capital to provide favorable support for the construction of sponge city. Pingxiang PPP model is social capital and Pingxiang Construction and Development Co., Ltd. to form a cooperative main body, in fact, social capital accounted for 70\%, Pingxiang Construction and Development Co., Ltd. Then through a third-party asset management company (Nanjing Zhuoyuan Asset Management Co., Ltd.) to determine the relevant content of the service. The joint venture company is responsible for the construction and management of the project and other specific affairs, in the actual operation of the project construction is divided into two parts. The central subsidy of the sponge city special construction funds are mainly used for the construction of public welfare facilities, water plants, pumping stations and other construction can obtain greater profits by social capital is responsible for the construction, in order to obtain investment returns. Another problem is that in the traditional water pricing, the original payment mechanism is relatively single, and the construction process involves complex charges, so combined with their own special circumstances, create a unique project income and return mechanism, according to the actual needs of the quotation, on this basis to facilitate administrative work.

\section{Background of Sponge City Construction in Pingxiang City}

\subsection{The General Situation and Background of Pingxiang}

Pingxiang is located in the west of Jiangxi province, south of the Qinling-Huaihe 
river line, the climate type belongs to the typical subtropical humid monsoon climate area, as shown in Table 1. Precipitation of the cities in the south of China is generally more than that in the north, and the total amount of rain in Pingxiang is larger than that in most cities in the south. As shown as Table 2. In the past, Pingxiang relied on its rich natural resources to develop its secondary industry for a long time, but the resources were always exhausted with the passage of time, excessive mining of coal, mountain excavation caused a shortage of resources, imbalance of ecological environment, and the development of the city encountered bottlenecks. People's harm to nature will always be retaliated by nature, and urban residents and rulers are troubled by the problem of heavy rainstorms and urban water accumulation. Therefore, it is put on the agenda to find a new direction for urban development, improve urban water accumulation and water shortage in dry season in Figure 1.

Table 1. Climate analysis table of pingxiang city.

\begin{tabular}{ccc}
\hline Humid subtropical monsoon & Climatic Characteristics & Temperature \\
\hline Summer & High temperature and rainy & Maximum temperature $41^{\circ} \mathrm{C}$ \\
Winter & Mild and little rain & Lowest temperature-9.3 ${ }^{\circ} \mathrm{C}$ \\
\hline
\end{tabular}

Table 2. Precipitation analysis in pingxiang city.

\begin{tabular}{ccccc}
\hline $\begin{array}{c}\text { Annual mean } \\
\text { precipitation }\end{array}$ & $\begin{array}{c}\text { Maximum annual } \\
\text { precipitation }\end{array}$ & $\begin{array}{c}\text { Maximum monthly } \\
\text { precipitation }\end{array}$ & $\begin{array}{c}\text { Maximum daily } \\
\text { precipitation }\end{array}$ & $\begin{array}{c}\text { Minimum annual } \\
\text { precipitation }\end{array}$ \\
\hline $1596.7 \mathrm{~mm}$ & $2184.0 \mathrm{~mm}$ & $659.4 \mathrm{~mm}$ & $225.6 \mathrm{~mm}$ & $1086.4 \mathrm{~mm}$ \\
\hline
\end{tabular}

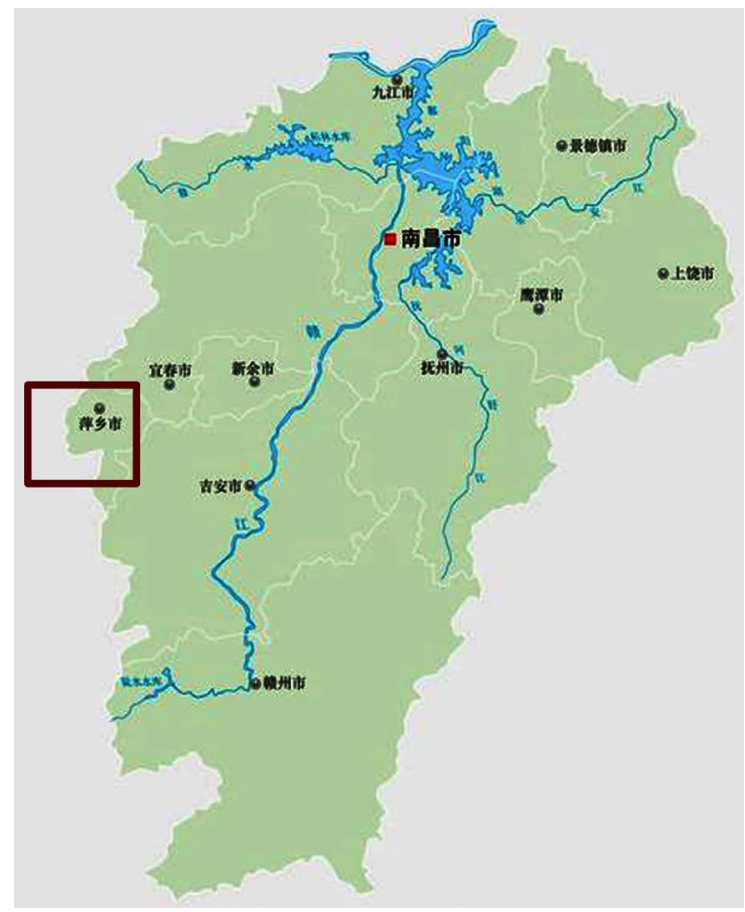

Figure 1. Geographical position. 
After the approval of the application of sponge cities for pilot cities, the preferred areas for flood disasters in old urban areas should be renovated, and then experimental transformation should be carried out in new districts and administrative districts of cities. Around Pingxiang's characteristics and ecological conservation development, Tianzhong Lake and its surrounding areas will be increased to form Pingxiang Sponge City Demonstration Zone, with a total area of 32.98 square kilometers. The general construction method of sponge city is to adopt the setting of sinking green space, to dig new or to use existing rivers and lakes as artificial reservoirs, to plant green plants on the roof, to transform the traditional impermeable gray pavement and road hardening into new permeable materials, and then to use additional measures such as planting grass ditches and biological detention to carry out effective management of runoff and rainwater [4]. Pingxiang City combines its own actual situation for planning and construction, and ultimately achieves the goal of groundwater supply and demand balance, and builds a unique new sponge city.

From Table 1 and Table 2, we can see that the precipitation in Pingxiang is different in time and space. Precipitation is mainly concentrated in summer, the time is concentrated and the amount of water is large. Nearly half of the annual amount of water comes from summer. Therefore, it is particularly important to use precipitation scientifically to alleviate the seasonal water shortage of the city. During the high water period, we can store and purify the rainwater through the new sponge. During the low water period, it can be used effectively. More importantly, it can improve the overall environment of the city and improve the quality of urbanization.

\subsection{Analysis of Present Situation and Existing Problems in Pingxiang}

\subsubsection{Waterlogging Risk}

Pingxiang city of the overall topography of the west is higher than the east, the city is surrounded by mountains on three sides, only Pingshui River in the region can accept the entire city's surface runoff, Pingshui River capacity will be limited will have a corresponding urban waterlogging problem.

\subsubsection{Runoff Pollution}

Pingxiang urban population density is relatively large, distribution of some factories and large enterprises, the city has half of the industrial sewage produced by these enterprises, a large number of sewage and wastewater discharge has become the main pollution source of Pingshui River, coupled with the unreasonable discharge of people's living water, environmental pollution and other factors cause poor water quality.

\subsubsection{Water Shortage}

According to the relevant water use report of Pingxiang City, the total amount of available water resources in Pingxiang City is about 938 - 13.3 billion cubic me- 
ters by the middle of the 21st century. It is clear that the demand for water is far greater than the total amount of water resources available, according to this trend, the city will fall into the panic of water shortage. Sponge city of natural precipitation storage, purification, reuse and a series of ways to use properly, can effectively fill the gap between supply and demand imbalance.

\subsection{Objectives and Strategies of Sponge City Construction}

\subsubsection{General Objectives of Sponge City Construction}

The implementation of planning and construction projects should be based on the principle of promoting harmony between man and nature, and on the basis of maintaining ecological balance to the maximum extent, so as to achieve the minimum human intervention, so as to maximize the use of rainwater resources and change the simple and extensive treatment mode of rainwater drainage in the past. After the transformation of the overall urban ecological environment has been improved, the heat island effect has been reduced accordingly, the status of water shortage in the project has been effectively alleviated, the overall image of the city has been improved, the living environment and living experience are better, which presents a good blueprint for the development of urban residents.

\subsubsection{Control Indicators of Sponge City Construction}

According to the general control index of sponge city and the actual situation of Pingxiang City, as shown as Table 3, the feasible control index suitable for the region is formulated, such as Table 4 .

\subsubsection{Sponge City Construction Strategy}

1) Constructing a global sponge system

The construction of the global sponge system is embodied in three aspects: the global management and control, the system construction and the district management. The construction of the sponge city in all directions and in many fields is not limited to laying permeable bricks, blindly building and rebuilding sewers, but to make full use of the existing rivers, lakes and ditches to form a drainage system of upstream water interception, midstream water storage and downstream water drainage on the basin scale. In the middle reaches of Wufeng river and pingshui river, the independent water landscape of Yuhu lake and pingshui lake is developed, the peak runoff of the two rivers can be adjusted by corresponding methods, and the drainage pressure of the existing river channel can be reduced. The zoning management mainly embodies in the analysis of the present situation of the old city, so as to adopt different management and construction measures to achieve the goal of sponge city construction. The construction of new urban areas should be strictly in accordance with the standards of sponge city construction, rational use of natural water storage structure, as much as possible use of pervious materials pavement, park green space construction to form a natural sponge network pattern, the old urban areas should be combined 
Table 3. Control indicators of sponge city construction.

\begin{tabular}{|c|c|c|c|c|c|c|c|}
\hline \multicolumn{2}{|c|}{ Water Ecology } & \multirow{2}{*}{$\begin{array}{c}\text { Water } \\
\begin{array}{c}\text { Environmental } \\
\text { Quality }\end{array} \\
\text { Rate of surface } \\
\text { water quality up to } \\
\text { standard }\end{array}$} & \multirow{2}{*}{$\begin{array}{c}\text { Water Resources } \\
\text { Rainwater Resource } \\
\text { Utilization Ratio }\end{array}$} & \multicolumn{4}{|c|}{ Flood Control and Drainage } \\
\hline $\begin{array}{c}\text { Rainfall } \\
\text { Retardation } \\
\text { Rate }\end{array}$ & $\begin{array}{c}\text { Water Area } \\
\text { Ratio }\end{array}$ & & & $\begin{array}{l}\text { RATE OF LEVEL } \\
\text { ACHIEVEMENT }\end{array}$ & $\begin{array}{c}\text { Drainage } \\
\text { compliance rate }\end{array}$ & $\begin{array}{c}\text { Flood Control } \\
\text { Standard }\end{array}$ & $\begin{array}{l}\text { Drainage } \\
\text { Standard }\end{array}$ \\
\hline 5 & 6.56 & 100 & 12 & 100 & 100 & $\begin{array}{l}\text { Once in } \\
50 \text { years }\end{array}$ & $\begin{array}{c}\text { Once in } \\
30 \text { YEARS }\end{array}$ \\
\hline
\end{tabular}

Table 4. Control indicators of sponge city construction in Pingxiang City.

When the daily precipitation is less than $30 \mathrm{~mm}$, no runoff occurs.

The water quality of the river in the demonstration area reaches the excellent level.

The utilization rate of rainwater resources is $12.5 \%$.

The flood control standard is that the main road of Pingshui River can withstand the flood once in 50 years, and the other tributaries can withstand the flood once in 20 years.

The runoff coefficient is less than 0.148 , that is, the total runoff control rate is more than $84.5 \%$.

When the rainfall is $22.3 \mathrm{~mm}$, the runoff is set at $76 \%$.

In the event of rainstorm once in 30 years, the total amount of runoff will not be controlled by $75 \%$.

with different areas of the special problems to be treated differently, specific analysis of specific problems, and gradually improve the waterlogging and flooding problems in recent years.

2) Establishment of sound working standards

According to the concepts of "natural accumulation, natural infiltration, natural purification" and "restoring the ecological environment of water body, improving the deteriorated water quality, conserving water sources, enhancing safety and security, and attaching importance to water culture" put forward by Sponge City, Pingxiang supplements and modifies the concepts on the basis of this concept, thus forming its own characteristic road of building sponge city. Effectively achieve the whole basin management and control, maximize the role of natural resources on rainwater savings, as far as possible the implementation of human intervention. Then a comprehensive customization of specific standards, change the previous technology is not comprehensive, non-standard implementation status. Finally, through the whole process, the whole field of development, coupled with the active cooperation of citizens to mobilize the enthusiasm of the people of the city, sponge city caused by the industrial chain to supplement a good battle.

And in the existing circumstances to develop practical work points, change the "terminal governance" construction method. Practice has proved that the drainage facilities to solve the problem of urban waterlogging effect is not obvious, the situation is still grim. System construction of sponge city system is a 
good method, sub-regional construction and transformation, to create a well-ordered system engineering. In addition to the use of PPP model, gradually let Pingxiang City in the sponge city pilot project achieved good results.

3) Establishing a set of long-term management mechanism.

Formulate a long-term management mechanism for the sponge city planning and construction work has a particularly far-reaching significance. In the planning and design, formulated a number of planning standards and rules, as an important part of the detailed planning of the city region. In the system system, from the administrative management, urban planning, fund management, construction management legislation, in the legal system to protect the sponge city construction, and special administrative personnel on the sponge project construction control. Of course, the most important and core is the technical guarantee, professional technicians and professional design team is the guarantee scheme feasible and widely promoted basis, without professional guidance, sponge city construction has become a paper empty talk, no operability to speak of.

4) Expanding multi-dimensional financing space

The construction of sponge city, not only need technical management and scientific planning, capital is equally important. Pingxiang city in the construction process has three sources of funds. First, the government independent financing (including bank loans, state financial allocations, sponge city special funds); second, the relevant departments of the city to invest; third, PPP model to attract social capital.

5) Explore the road of characteristic innovation of urban development

Innovation is the lifeline for all walks of life to progress, but also the only way for urban survival and development, sponge city construction is an important measure for Pingxiang to carry out urban construction at this stage, through changing the traditional development mode, renewing the development concept, changing the industrial pattern of the city, improving the utilization rate of water resources, relying on energy to develop heavy industry model to be transformed. At the same time, a series of industrial enterprises associated with the construction of sponge city came into being, which is very beneficial to the overall development of the city. For example, the construction of a large number of factories producing new permeable materials not only forms a new economic growth point, but also provides corresponding jobs.

So far, Pingxiang sponge city has completed more than 100 pilot projects, with a total investment of nearly 6 billion. Since the sponge city became a pilot city in Pingxiang, after several years of construction, the overall style of the city has been greatly improved, and the transformation of the city has been realized. The basic municipal facilities of the city have been improved, the problems of water pollution and shortage of water resources have been alleviated, and the overall ecological environment of the city has been greatly improved, and a satisfactory answer has been submitted to the urban people. 


\section{Specific Measures for the Construction of Pingxiang Sponge City}

\subsection{Use Permeable Materials to Renovate Existing Vehicle Pavements and Sidewalks}

The traditional road and pavement mostly use high strength impermeable materials, rainwater can only be drained through a single way, if it is a short time of precipitation is not enough to lead to road surface water, but the current climate due to excessive human intervention, with great instability, extreme weather increased. But if rainwater can be absorbed by land, vegetation, rivers, lakes and seas like the original environment, it can fundamentally solve the problem, so the use of new pervious materials can just restore the environment before artificial transformation to a greater extent, part of the rainwater is absorbed by laying materials, which not only reduces the moisture on the road surface, but also alleviates the pressure of drainage facilities.

\subsection{Green Belt into Sponge City Design Concept}

Effective use of urban green belt can have many benefits. On the one hand, it can beautify the environment, but also play a role in purifying the air and contribute to environmental protection. On the other hand, after a certain treatment can also play an auxiliary role in the construction of sponge city. In the choice of planting soil, priority should be given to the use of soft soil for water storage and moisture conservation under the first layer of gravel, such a way of laying can maximize the accumulation of rainwater. In the choice of plant species, we should also try to choose the type of plants that can conserve water and soil. Green belt planting can form a spongy organization with permeable pavement to absorb rainwater together. At the same time, if properly handled, it can also play a role in purifying and filtering rainwater. The combination of seepage materials and planting soil plays a role in absorbing and filtering rainwater, and scientific design and management is the guarantee for the actual implementation. Combined with the joint action of surface open ditch and underground ditch, a huge water storage and storage system has been formed.

\subsection{Details of Other Related Facilities}

A complete road system consists of hardened surface, green belt, kerb stone, shoulder, edge ditch design, in addition to hardened surface and green belt these more important main parts, the design of small details such as kerb stone is equally important. The two common methods of laying kerb stone are tiling and standing. If tiling, it can be slightly inclined at an angle, so that rainwater can flow along this angle to the side ditch or green belt on both sides of the road. Compared with flat paving, there are some limitations, water can only flow down the pre-drilled holes, flow and flow rate are somewhat slow, unless the material uses a new pervious type, it cannot meet the drainage needs of sponge cities [5]. 


\subsection{Connection with Urban Green Space}

The main body of sponge city construction is the city, so the cooperation of all components in the city is very important. In the completed projects, advanced LID source infiltration technology is adopted, supplemented by the necessary construction of regulation ponds and infiltration canals. In areas where the total amount of rainwater is large, rainwater interception and purification are adopted first, and water can be stored in green space through seepage technology after treatment. Water shortage areas should give full play to the power of sponge city facilities on the basis of existing facilities, maximize the use of rainwater, and alleviate the current situation of water shortage.

\section{Achievements of Sponge City Construction in Pingxiang City}

\subsection{Improvement of the Overall Urban Landscape}

Pingxiang used to be famous for its coal industry. The first impression of coal is black and dust. The long-term mining of coal has directly brought about environmental pollution and resource depletion. Environmental pollution is mainly reflected in the deterioration of urban air and water resources, and environmental problems are unprecedented serious. However, after the transformation, urban greening has increased significantly, and the water quality of the river has also been greatly improved. Trees are shady, birds and flowers are fragrant, the environment is beautiful, and human settlements are harmonious. Changing the image of the past, the city has not only changed its appearance but also its temperament as a whole.

\subsection{Community Transformation Is Popular}

Pingxiang sponge city construction first in part of the district. Before the transformation of the district state is chaotic, rainwater and sewage mixed discharge, caused pollution to the water quality, the overall image of the district is not very good. Can not meet the current stage of people's high quality of life requirements. The transformation mainly focuses on the existing water treatment to promote the improvement of the water quality of the whole city. Through increasing greening to enhance the ability of soil and water conservation. Reforming the existing rainwater drainage facilities to realize rain and sewage diversion. A series of procedures for collecting, treating and purifying the rainwater on the roof and on the road surface to filter and purify the rainwater. The transformed residential area has increased some new facilities for treating and collecting rainwater, which is beautiful and of great use value. It also maximizes the utilization rate of rainwater. The road surface of the residential area where there was no place for rain before does not exist, and now the road surface is dry and clean. Similar residential similar transformation methods have achieved good results, roof, road, green water has a special rainwater collection pipe network, 
and then through these pipe network discharge to the detention pool and sunken green [6]. Sponge city and every urban residents experience is closely related, will also be more and more people's attention.

\subsection{The Park Has Achieved Fruitful Results}

Yuhu Park, Goose Lake Park, Jinluofeng Park and other parks have also achieved great results. The construction of Yuhu Park is expected to create a clean, comfortable, beautiful public space, invested 140 million yuan to build it into a park with entertainment, fitness, viewing and other activities. Yuhu Park from the original a small reservoir changed, the corresponding supporting facilities have been greatly enriched and improved. Small square, wooden trestle road, sightseeing hall and fitness trail are all available, which not only facilitate people's life, but also communicate with the concept of sponge city, the corresponding green space transformation, the large-scale use of permeable pavement and the overall environment complement each other. The technology and concept of sponge city used by Yuhu Park has become a model project, and also provides construction guidance for the later transformation of parks. Goose Lake Park and Jinluofeng Park have also achieved remarkable results [7].

\section{Conclusion}

In the final analysis, sponge city is to solve the city's water problems, including water safety, construction methods, administrative law enforcement, system governance issues and so on, which are the problems we have to face and solve. Pingxiang sponge city construction has achieved good results, which can provide relevant cities with experience and learning methods. But many practices can not adapt to the present unchanged, with the progress of society and the development of the times to improve and further improve. At present, there are still many small and medium-sized cities in our country facing the problem of urban waterlogging, these cities can learn from the experience of the reconstruction of the city, and plan their own construction road, economic development to a certain extent, people pay attention to the quality of life and ecological environment, and the construction of sponge city can meet people's mentality of upgrading and improving the status quo.

\section{Conflicts of Interest}

The authors declare no conflicts of interest regarding the publication of this paper.

\section{References}

[1] Liu, B. (2014) Sponge City Technology Is the Starting Point of China's Urban and Rural Ecological Environment Construction. Living, No. 12, 42-45.

[2] Ministry of Finance of the People's Republic of China (2015) Publication of the List of Pilot Cities for Sponge City Construction in 2015. 
[3] Ju, M.S. (2015) Thoughts on the Concept, Technology and Policy of Sponge City Construction. Research on Water Conservancy Development, 15, 7-10.

[4] Ji, J.H. (2017) On the Application of Sponge City in the Design of Water Supply and Drainage of Municipal Roads. Doors and Windows, 8, 150.

[5] Wu, W.-H. (2017) Brief Analysis on the Technical Points of Sidewalk Construction of Municipal Road in Sponge City. Jiangxi Building Materials, No. 23, 183-189.

[6] Ministry of Housing and Urban-Rural Construction, Technical Guidelines for Sponge City Construction (Trial Implementation) (2015) (Abstract) Construction of Low Impact Development Rainwater System. Building Block and Block Building, No. 1, 45-50.

[7] Pingxiang Municipal People's Government (2015) Three-Year Action Plan for the Pilot Construction of Pingxiang Sponge City (2015-2017). 